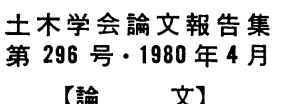

【論 文】

\title{
補剛された圧縮板の弾塑性有限変位挙動の一解析手法 \\ ELASTO-PLASTIC FINITE DISPLACEMENT ANALYSIS OF LONGITUDINALLY STIFFENED PLATES IN COMPRESSION
}

\author{
小松 定 夫*・北田 俊 行** \\ By Sadao KOMATSU and Toshiyuki KITADA
}

\section{1. まえがき}

本論文においては，初期たわみや残留応力などの初期 不整を有し，面内圧縮力を受ける補剛板が極限状態を過 ぎるまでの弾塑性有限変位挙動の解析法について論じて いる. 本法は次のような意味で悠密解析法とみなすこと ができる.

(1) 補剛板を直交異方性板として理想化せず，補剛材 と板パネルからなる薄板と柱の集成モデルとしてい るため, 補剛材間の板パネルの局部变形挙動および 応力の不均一性を明白にできる.

(2) 線形座屈理論に基づく固有值問題（分岐問題）と しては取り扱わないで, 補剛板の荷重変位曲線およ び応力の変動状況を有限変位理論の立場から追跡し その極限強度を求めている.

圧縮補剛板の弾性もしくは弾塑性の悠密解析を実施す るうえで, 研究者が直面する問題は，“多自由度の非線 形挙動をいかに処理するか”ということである. 圧縮板 の弾塑性有限変位解析法については, すでに, MurrayWilson (1969), 大坪 (1971), Moxham (1971), 岡村 • 吉田 (1972), 上田・山川・藤原 (1973), 上田・安川・ 矢尾・池上・大南 (1975), 小松・北田・宮崎 (1975), Crisfield (1975), Needleman-Tvergaard (1976), Harding-Hobbs-Neal (1977) らにより報告されている ${ }^{14), 16)}$. 等方性圧縮板の極限強度を取り扱うような比較的簡単な モデルを対象とする場合には，これらの解析法を適用す れば十分であると考える。しかし，補剛板などのような 複雑な薄肉構造物の極限強度の解析に対しては, 実用的 および経済的見地からより效率のよい厳密解析法の出現 が望まれている。

まず, Bilstein ${ }^{1)}$ は，等方性板の有限変位 $w$ と Airy

* 正会負 工博 大阪大学教授 工学部土木工学教室

** 正会員 工修 大阪市立大学講師 工学部土木工学教室
の応力関数 $F$ に関する 非線形 2 元連立偏微分方程式を 取り扱った．面内のつり合い関する方程式については 㛜密に，面外のつり合いに関する方程式については Galerkin 法を適用している. 数值計算には標準的なRungeKutta 法を用いている．補剛材等の存在による横方向へ の形状等の非連続性については，改良された還元法を用 いて対処している. また, 補剛材先端での縦方向応力度 㐫るいは板パネルの縦方向膜応力度のいずれかが降伏点 に達したときを近似的に補剛板の極限状態と定義してい る. しかし, これは真の意味ではあくまで弾性解析の範 囲内にとどまっており，極限状態とはいい難い。また初 期たわみについて考虑しているが，残留応力については 何の取り扱いもなされていない。この方法では, 補剛板 全体のたわみ波形と補剛材間の板パネルの局部的なたわ み波形が連成して極限状態に至るような実際的な補剛板 の解析ができないといら久点がある.

岡村・吉田 ${ }^{2(4)}$ は, 面外の曲げモーメントと面内力が 作用した場合の板内の塑性化した点（板厚方向への塑性 の広がりは無視) での降伏曲面を近似式で仮定し, 薄板 の弾塑性有限変位挙動を支配するところの，たわみ w と応力関数 $F$ に関する非線形 2 元連立偏微分方程式を 誘導している. そして,たわみ $w$, 応力関数 $F$, 板内に 設けられた格子状の選点における有限変位および塑性変 形に伴ら非線形物理量 $(I, \Lambda)$ および $(\psi, \Gamma)$ ならびに 補剛材と板との接合線上の選点における不静定合成力お よび板の周辺での境界条件を満足させるために設けられ た周辺上の選点における不静定拘束力をすべて 2 重 3 角 級数で表わし，上述の非線形偏微分方程式の連続関数解 を得ている.計算にあたっては,最初から未知の量 $I, A$, $\psi ， \Gamma$ が存在するため, 初期荷重法的な反復法を用いて いる．この論文では，初期たわみを有する種々の圧縮板 について解析を行っているが，補剛板の残留応力につい ては触れていない。

山田・渡辺 $\left.{ }^{5)}, 6\right)$ ( 
後座屈強度の解析を行っている. その際, 材料学的非線 形性を一般的な形で取り扱えば解析が煩雑になるという 理由から, 板は弾性挙動のみを呈し, 補剛材だけが弾塑 性挙動を呈するものと仮定し, 準弾塑性的な解析を行っ ている. また, 非線形の解法には摂動法を用いている. 上田・矢尾・菊本 ${ }^{7)}$ も有限要素法を用いた解析を行っ ている.この論文では, 材料学的非線形性については塑 性流れ理論を用い板厚方向への塑性域の広がりを考慮し た厳密な取り扱いを行っている．また，増分法により， 非線形の基礎方程式を線形化している.

補剛材本数の多い補剛板の解析や, 圧縮補剛板の極限 強度特性を明らかにするために必要なパラメトリック解 析を行う場合には, 通常の有限要素法よりも計算効率が よく,また，精度もよい数值計算手法の開発が望まれ る. Y.K. Cheung ${ }^{8)}$ が考案した有限帯板法はこの種の 問題点を解決するための解析手法でもある. すなわち, 板要素を細長い帯板の集合体にモデル化し, 各帯板要素 内の変位を長手方向の座標の有限 3 角級数で仮定し, 自 由度の節減を行っている. 上田・松石・山内・田中 ${ }^{97}$ お よび上田・松石・森・村川 ${ }^{10)}$ は, この帯板要素法を用い て，曲げを受ける桁の横倒れに関する弾塑性有限変位解 析を行っている. 非線形の解析には増分法を用いてお り, その計算過程で帯板要素の板面内方向および板厚方 向への塑性の広がりの判定については，あらかじめ要素 内に設定した 3 次元格子点で行い, また, 接線剛性マト リックスの数值積分については，この格子点での前荷重 段階における応力, ひずみおよび変位を用いて実行して いる.

同様な見地から, 大坪 $\left.{ }^{11)}, 12\right)$ も圧縮板の 弾塑性有限変 位解析を行っている. この方法では, 板の面内挙動に対 しては有限要素法を用い, 面外挙動に対してはたわみ波 形の単調性を利用して, それを数項の 3 角級数に展開す ることにより自由度の節減を図っている. TvergaardNeedleman ${ }^{13)}$ は大坪の方法を圧縮補剛板の弾塑性㛜密 解析に応用している. これらの研究においても残留応力 についてはなんら取り扱っていない. 彼らは, 面内およ び面外変位とも級数で仮定した場合，すなわち完全な Rayleigh-Ritz 法を用いた場合と，面内挙動に対しては 有限要素法を用いる Rayleigh-Ritz 法との混用法を用い た場合の両者を比較して次のような結論を得ている. 彼 が行った解析モデルでは, 完全な Rayleigh-Ritz 法の場 合, 混用法と同じ精度の結果を得るためには 27 項の面 内変位モードが必要となり, その計算時間が混用法の場 合の 2 倍必要になったと報告している. そして，一般的 に, 面外変位に比べて面内変位に関しては, その変位モ ードを推定することが非常に難しく，このことが混用法 を非常にアトラクティブな解析手法にしていると述べて
いる.このような現状にかんがみ，本文では，初期たわ みと残留応力を同時に有する圧縮補剛板の弾塑性厳密解 析を行っている. 本法においては, 面内挙動に対しては 従来どおりの有限要素法に従い, 面外挙動に対しては たわみ波形を数項のたわみモードでもって表現し, 自由 度の低減を行っている.ただし, 有限要素の各節点での たわみは, あるモードで仮定するが, 各要素内のたわみ は従来の有限要素法と同様, 多項式で与えている. 大坪 の方法と本法を比較した場合, 前者では, 要素内のすべ ての点のたわみを 3 角級数で表現しているのに対して本 法では, 全補剛板についてたわみを 3 角級数で表現し, そのうえに要素の節点のたわみを乗せるような形で仮定 し, 要素内のたわみについては, 別途に局所座標の 3 次 関数で表現している. そのため本法では次のような特長 がある。

(1) 従来の有限要素法のみのプログラムに若干の修正 を加えることにより, 大幅な自由度の低減が可能と なる.

(2) したがって，解析する圧縮板の境界条件が異な り，仮定するたわみモードが変化しても，若干のプ ログラムの修正で対処することができる.

(3) 有限要素内では従来どおりの多項式の変位関数を 用いているため, すでに誘導された剛性マトリック スをそのまま用いることができる.

(4) 数值計算においては, モード化したたわみおよび たわみ角の節点での值のみしか必要とせず, $\sin , \cos$ の複雑な積分は不要となり, 計算効率が向上する. 以下, 本解析法の理論を述べ, その精度, 計算時間, 計算に必要な記憶容量について考察を加える.さらに, 実験值と本解析結果を比較し, 本法の妥当性を立証して いる.

なお, 本論文では簡単のため, 載荷辺の板パネル中央 面に一方向の一様相対圧縮変位を作用させた場合の解析 について述べることにするが，任意の位置に載荷した場 合についても取り扱うことができる.

また, 本法の適用範囲の問題については, 以下のよう に考えられる.

1）本法においては, Rayleigh-Ritz 法および Galerkin 法と同様，境界条件および荷重条件によりその 適用範囲に制限を受けている。しかし，本論文で取 り扱うような面内圧縮力を受ける周辺単純支持の長 方形補剛板では，この適用範囲の制限は問題になら ない.

2) 次に, 2 重 3 角級数による変位場の表現に関して は, 次のように考えられる. 本法では, 周辺単純支 持の補剛板のたわみを 2 重 3 角級数に展開している が，これは従来の弾性座屈理論による変位の級数解 
（厳密解）にほかならない。したがって，応力状態 のいかんにかかわらず弾塑性座屈の正確解に収束す るものと考えられる．なお，応力状態によっては， 複雑なたわみ波形になると考えられる。このような 場合, 通常の有限要素法のみを用いるとメッシュ分 割を細かくする必要があり，自由度が増大する．と ころが，本法を用いると，級数の項数は増大寸る が，大幅な自由度の節減が期待できる。

\section{2. モデル化}

図一1に示すように, 補剛材部は直線の柱要素, 板パ ネル部は平面の三角形板要素の集合体として補剛板をモ デル化する. 補剛材は開断面のものを対象にしているた めそその㸚じり剛性は一応無視することにする.

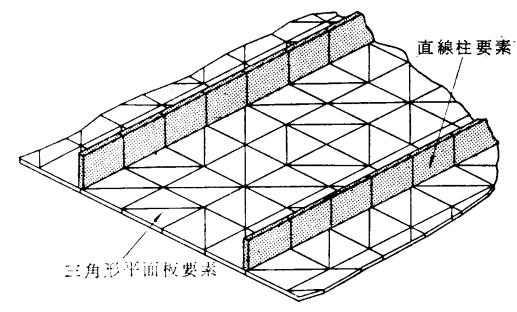

図一1 有限要素によるモデル化

\section{3. 解析理論}

本解析理論は, 有限要素法のみを用いた圧縮板の弾塑 性有限変位解析法 ${ }^{14)}$ を圧縮補剛板に拉張し，それにモー ダル・アナリシス的手法を導入したものである．したが ってここでは, 文献 14）の方法と異なる点および改良し た点のみを以下に記述することにする.

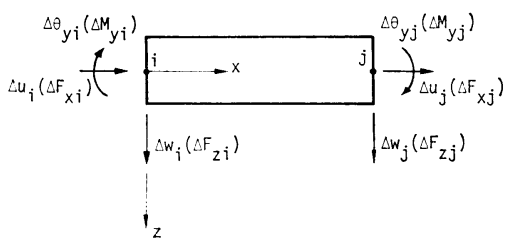

\section{図一2 柱要素の要素座標, 節点変位增分 および節点力增分}

\section{（1）変位增分の推定}

つり合い状態 $\mathrm{M}$ から, 次のつり合い状態 $\mathrm{M}+1$ 亿至 る反復計算の過程で, 状態 M から出発して I 回目の反 復状態 I をまず求め, それから次の反復点である状態 I +1 に至る計算過程について考える. この計算過程に おけるある板要素 $k$ のひずみ増分ベクトル $\Delta \boldsymbol{\varepsilon}_{I}$ は文献 14）の式 (2.2.4) より,

$$
\begin{aligned}
\Delta \varepsilon_{I}= & B_{u} \cdot \Delta d_{s I}+\frac{1}{2} \cdot \Delta C_{\theta} \cdot A_{\theta} \cdot \Delta d_{b I} \\
& +C_{\theta I} \cdot A_{\theta} \cdot \Delta d_{b I}-z \cdot A_{\phi} \cdot \Delta d_{b I}
\end{aligned}
$$

ここに, $\Delta \boldsymbol{d}_{s I}, \Delta \boldsymbol{d}_{b I}$ は，それぞれ状態 I における面内 および面外の節点変位増分ベクトルであり, $\boldsymbol{B}_{u}, \boldsymbol{A}_{\theta}, \boldsymbol{A}_{\phi}$ は，それぞれ，板中央面におけるひずみ増分と $\Delta d_{s I}$, た わみ角増分と $\Delta d_{b I}$, 曲率増分と $\Delta d_{b I}$ を関係ゔける トリックスであり， $\boldsymbol{C}_{\theta I}, \Delta \boldsymbol{C}_{\theta I}$ は，それぞれ，たわみ角 およびたわみ角増分に関するマトリックスである. 応力 増分ベクトル $\Delta \sigma_{I}$ は文献 14) の式 (2.2.7) より,

$$
\Delta \boldsymbol{\sigma}_{I}=D_{I} \cdot \Delta \varepsilon_{I}
$$

図一2 に示すような柱要素においても, その節点変位増 分ベクトルを板要素と同じ記号で以下のように表わす.

$$
\begin{aligned}
& \Delta \boldsymbol{d}_{s I}=\left\{\Delta u_{i} ; \Delta u_{j}\right\}_{I}{ }^{*} \\
& \Delta \boldsymbol{d}_{b I}=\left\{\Delta w_{i} ; \Delta \theta_{y i} ; \Delta w_{j} ; \Delta \theta_{y j}\right\}_{I}
\end{aligned}
$$

すると，柱要素内に生じるひずみ増分 $\Delta \varepsilon_{x I}$ および応力 増分 $\Delta \sigma_{x I}$ も式 (1)，(2) と同じ式で表わすことができ る.ただし, 柱要素の場合には,

$$
\begin{aligned}
& \Delta \boldsymbol{\varepsilon}_{I}=\Delta \varepsilon_{x I}, \Delta \boldsymbol{\sigma}_{I}=\Delta \sigma_{x I}, \Delta \boldsymbol{C}_{\theta}=\Delta \boldsymbol{d}_{b I}{ }^{T} \cdot \boldsymbol{A}_{\theta}{ }^{T}, \\
& \boldsymbol{C}_{\theta I}=\boldsymbol{d}_{b I}{ }^{T} \cdot \boldsymbol{A}_{\theta}{ }^{T}, \boldsymbol{D}_{I}=D_{I}=\Delta \sigma_{x I} / \Delta \varepsilon_{x I}
\end{aligned}
$$

ここで, $D_{I}$ は補剛材の材料接線係数で,

$$
D_{I}= \begin{cases}E & \text { (弾性の場合, ヤング係数 }) \\ E_{T} & \text { (塑性の場合, 接線弾性係数 })\end{cases}
$$

以下, 板要素および柱要素を含めた任意要素 $k$ のひず み増分ベクトルおよび応力増分べクトルを式 (1)，(2) で表わすことにする.

要素 $k$ の状態 I に㧍ける応力度ベクトルを $\boldsymbol{\sigma}_{I}$, 節点 カベクトルを $f_{I}$, 節点変位ベクトルを $d_{I}, \mathrm{I}$ から $\mathrm{I}+1$ に至る節点力増分ベクトルを $\Delta \boldsymbol{f}_{I}$, 節点変位増分ベクト ルを $\Delta \boldsymbol{d}_{\boldsymbol{I}}$ とすると, 状態 $\mathrm{I}+1$ における要素 $k$ のポテ ンシャルエネルギー II は次のようになる.

$$
\Pi=U-\left(d_{I}+\Delta d_{I}\right)^{T} \cdot\left(f_{I}+\Delta f_{I}\right) \cdots
$$

ここで, $U$ はひずみエネルギーで,

$$
U=U_{0}+\Delta U \text {. }
$$

$U_{0}$ は状態 I でのひずみエネルギーで， $\Delta U$ は，

$$
\Delta U=\int_{V}\left(\Delta \boldsymbol{\varepsilon}_{I}^{T} \cdot \boldsymbol{\sigma}_{I}+\frac{1}{2} \cdot \Delta \boldsymbol{\varepsilon}_{I}^{T} \cdot \boldsymbol{D}_{I} \cdot \Delta \boldsymbol{\varepsilon}_{I}\right) d x d y d z
$$

状態 I での補剛板を直線あるいは平面の有限要素の集 合体で近似する.すなおち，

$$
\boldsymbol{C}_{\theta I}=\mathbf{0}
$$

式 (1)，（2）を式（13）に代入し, 増分変位の 3 次以上 の項を無視すると，

$$
\Delta U=\Delta d_{I}{ }^{T} \cdot f_{I}+\frac{1}{2} \cdot \Delta d_{I}{ }^{T} \cdot k_{I} \cdot \Delta d_{I} \cdot
$$

ここで, $\boldsymbol{k}_{I}$ は, 要素の接線剛性マトリックスであり,

*) \{ ；＼$は列ベクトルを表わす. }$ 


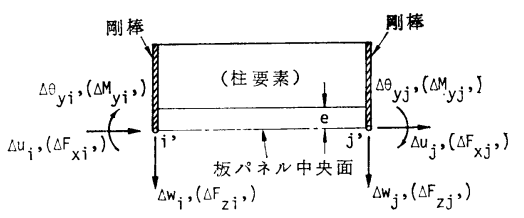

図一3 オフセットビーム

板要素の場合には, $15 \times 15$ のマトリックスであり, 柱 要素の場合には，これに対応する $6 \times 6$ のマトリックス となる.さらに柱要素の場合, 図一3 に示すオフセット ビームの考え方を用いて, 図一2 に示す補剛材重心軸上 にある節点 $i, j$ での節点力増分ベクトル $\Delta \boldsymbol{f}_{I}$ および節 点変位増分ベクトル $\Delta \boldsymbol{d}_{I}$ を 図一3 に示す板パネルの中 央面内に設けた節点 $i^{\prime}, j^{\prime}$ での節点力増分ベクトル $\Delta \boldsymbol{f}_{I}{ }^{\prime}$ および節点変位増分べクトル $\Delta \boldsymbol{d}_{I}{ }^{\prime}$ に関係づける.すな わち,

$$
\begin{aligned}
& \Delta \boldsymbol{d}_{I}=\boldsymbol{B} \cdot \Delta \boldsymbol{d}_{I}{ }^{\prime} \\
& \Delta \boldsymbol{f}_{I^{\prime}}=\boldsymbol{B}^{T} \cdot \Delta \boldsymbol{f}_{I}
\end{aligned}
$$

ここで, 柱要素の場合,

$$
\Delta \boldsymbol{d}_{I}{ }^{\prime}=\left\{\Delta u_{i}{ }^{\prime} ; \Delta w_{i}{ }^{\prime} ; \Delta \theta_{y i}{ }^{\prime} ; \Delta u_{j}{ }^{\prime} ; \Delta w_{j}{ }^{\prime} ; \Delta \theta_{y j}{ }^{\prime}\right\}
$$

$$
\begin{aligned}
& \Delta \boldsymbol{f}_{I}{ }^{\prime}=\left\{\Delta F_{x i}{ }^{\prime} ; \Delta F_{z i}{ }^{\prime} ; \Delta M_{y i}{ }^{\prime} ; \Delta F_{x j}{ }^{\prime} ;\right. \\
& \left.\Delta F_{z j^{\prime}} ; \Delta M_{y j}{ }^{\prime}\right\} \ldots \ldots \ldots . . . \\
& \boldsymbol{B}=\left[\begin{array}{cccccc}
1 & 0 & -e & 0 & 0 & 0 \\
0 & 0 & 0 & 1 & 0 & -e \\
0 & 1 & 0 & 0 & 0 & 0 \\
0 & 0 & 1 & 0 & 0 & 0 \\
0 & 0 & 0 & 0 & 1 & 0 \\
0 & 0 & 0 & 0 & 0 & 1
\end{array}\right] \ldots \ldots . . .
\end{aligned}
$$

また, 板要素の場合, マトリックス $\boldsymbol{B}$ はベクトル $\Delta \boldsymbol{d}_{I}$, $\Delta \boldsymbol{f}_{I}$ の要素を式 (21)，(22）に示すように並び変えるマ トリックスとなる.

$$
\begin{aligned}
\Delta \boldsymbol{d}_{I}{ }^{\prime}= & \left\{\Delta u_{i} ; \Delta v_{i} ; \Delta w_{i} ; \Delta \theta_{x i} ; \Delta \theta_{y i} ; \Delta u_{j} ;\right. \\
& \Delta v_{j} ; \Delta w_{j} ; \Delta \theta_{x j} ; \Delta \theta_{y j} ; \Delta u_{k} ; \Delta v_{k} ; \\
& \left.\Delta w_{k} ; \Delta \theta_{x k} ; \Delta \theta_{y k}\right\} \cdots \cdots \cdots \cdots \cdots \cdots \cdots \\
\Delta \boldsymbol{f}_{I}{ }^{\prime}=\{ & \Delta F_{x i} ; \Delta F_{y i} ; \Delta F_{z i} ; \Delta M_{x i} ; \Delta M_{y i} ; \\
& \Delta F_{x j} ; \Delta F_{y j} ; \Delta F_{z j} ; \Delta M_{x j} ; \Delta M_{y j} ; \\
& \left.\Delta F_{x k} ; \Delta F_{y k} ; \Delta F_{z k} ; \Delta M_{x k} ; \Delta M_{y k}\right\}
\end{aligned}
$$

さらに, 要素座標系に打ける変位増分ベクトル $\Delta \boldsymbol{d}_{I}{ }^{\prime}$ を 全体座標系に㧍ける変位増分ベクトル $\Delta \boldsymbol{u}_{I}{ }^{(k)}$ に置換す ると,

$$
\Delta d_{I}{ }^{\prime}=L_{I} \cdot \Delta u_{I}^{(k)}
$$

ここで， $L_{I}$ は座標変換マトリックスである.

さて, 補剛板の節点のたわみ $W$ を幾何学的な境界条 件を満足する有限項の 2 重 3 角級数として表わすことを 考える. そして, その 2 重 3 角級数の係数ベクトルであ る一般化変位増分ベクトル $\Delta \tilde{\boldsymbol{u}}_{I}$ で任意要素 $k$ の節点変
位増分ベクトル $\Delta u_{I}{ }^{(k)}$ を表わすと，

$$
\Delta \boldsymbol{u}_{I}^{(k)}=\boldsymbol{H}_{k} \cdot \Delta \tilde{\boldsymbol{u}}_{I} \cdot
$$

ここに, $\boldsymbol{H}_{k}$ は $m$ 行 $n$ 列の変換マトリックスであり, $m<n$ である. 本論文で取り扱うような周辺単純支持 の長方形圧縮補剛板のような構造物の場合には, 式 (24) により数個の一般化変位増分で各節点における变位増分 を表わすことができ，大幅な 自由度の節減が 可能にな るわけである. 式 (24) を式 (23), 式 (23) を式 (16) と順次代入し式 (11) をで至り $I I$ を求め, $\Delta \tilde{\boldsymbol{u}}_{I}$ の変分 $\delta \Delta \tilde{\boldsymbol{u}}_{I}$ に対する $\Pi$ の変分 $\delta \Pi$ を計算すると，

$$
\delta \Pi=\delta \Delta \tilde{\boldsymbol{u}}_{I}^{(k) T} \cdot\left\{\tilde{\boldsymbol{k}}_{I} \cdot \tilde{\boldsymbol{u}}_{I}^{(k)}-\Delta \tilde{\boldsymbol{f}}_{I}\right\}
$$

ここで,

$$
\begin{aligned}
& k_{I}=H_{k}^{T} \cdot L_{I}^{T} \cdot B^{T} \cdot k_{I} \cdot B \cdot L_{I} \cdot H_{k} \\
& \Delta \tilde{f}_{I}=H_{k}^{T} \cdot L_{I}^{T} \cdot B^{T} \cdot \Delta f_{I} \ldots \ldots \ldots \ldots \ldots
\end{aligned}
$$

式（25）のô を全要素について集成し, 系全体のポテ ンシャルエネルギー極小の原理を適用すると，

$$
\Delta \tilde{\boldsymbol{p}}_{I}=\tilde{\boldsymbol{K}}_{I} \cdot \Delta \tilde{\boldsymbol{u}}_{I}
$$

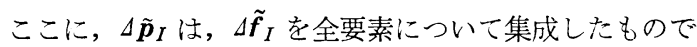
ある・

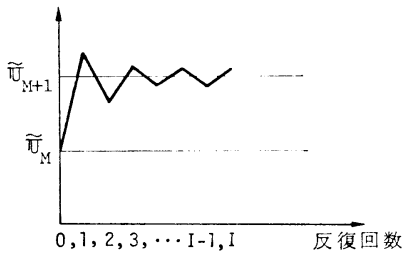

図一4 収束しない反復計算

式（28）を解くことにより $\Delta \tilde{\boldsymbol{u}}_{I}$ が求まり，状態 I+1 が定まる，ただし，本解析法では，式（14）の仮定を用 いているため, 補剛板の変形が大きくなると図一4に示 すように振動して，たまには，真值 $\tilde{\boldsymbol{u}}_{M+1}$ に収束しない 場合がある.この場合には, 次式により変位増分バクト ル $\Delta \tilde{\boldsymbol{u}}_{I+1}$ を考慮することによりらまく収束させること ができる.

$$
\Delta \tilde{\boldsymbol{u}}_{I+1}=\frac{1}{2}\left\{\Delta \tilde{\boldsymbol{u}}_{I}+\Delta \tilde{\boldsymbol{u}}_{I-1}\right\}
$$

\section{(2) 不つり合い力 $\tilde{\boldsymbol{r}}_{I+1}$ の計算}

不つり合い力の計算には文献 14) で示した剛体変位を 除去する方法を用いる.

状態 $M$ から状態 $\mathrm{I}+1$ までの剛体変位を除去した要 素 $k$ の節点变位増分ベクトルを $\Delta \overline{\boldsymbol{u}}_{M}$ とする. すると， 状態 $I+1$ での真の節点力ベクトル $\overline{\boldsymbol{f}}_{I+1}$ は次のように なる.

$$
\overline{\boldsymbol{f}}_{I+1}=\overline{\boldsymbol{f}}_{M}+\Delta \overline{\boldsymbol{f}}_{M}+\boldsymbol{f}_{r}
$$

ここで,

$$
\Delta \overline{\boldsymbol{f}}_{M}=k_{M} \cdot \Delta \overline{\boldsymbol{u}}_{M} \cdot
$$

$\overline{\boldsymbol{f}}_{M}$ : 状態 $\mathrm{M}$ での真の節点力ベクトル, $\boldsymbol{f}_{r}$ : 残留応 
カによる節点力ベクトル， $\boldsymbol{k}_{M}$ : 剛体変位を除去した変 位に微小変形理論を適用して導いた剛性マトリックス で, 板要素の場合には文献 14) の式 (2.4.11) に示した 剛性マトリックスであり, 柱要素についても板要素の特 別の場合として導くことができる. 式 (30) の真の節点 カベクトル $\boldsymbol{f}_{I+1}$ をモード化した一般化力ベクトル $\tilde{\tilde{f}}_{I+1}$ に変換すると，

$$
\widetilde{\overline{\boldsymbol{f}}}_{I+1}=\left(\widetilde{\overline{\boldsymbol{f}}}_{M}+\Delta \widetilde{\overline{\boldsymbol{f}}}_{M}\right)+\boldsymbol{H}_{k}{ }^{T} \overline{\boldsymbol{f}}_{r}
$$

ここで,

$$
\begin{aligned}
& \widetilde{\widetilde{f}}_{M}+\Delta \widetilde{\bar{f}}_{M}=\boldsymbol{H}_{k}{ }^{T} \cdot L_{I+1}{ }^{T} \cdot B^{T} \cdot\left(\overline{\boldsymbol{f}}_{M}+\Delta \overline{\boldsymbol{f}}_{M}\right) \\
& \overline{\boldsymbol{f}}_{r}=L_{I+1}{ }^{T} \cdot B^{T} \cdot f_{r}
\end{aligned}
$$

すべての要素について式 (32) を集成すると, 全節点に おける真の一般化力ベクトル $\tilde{\overline{\boldsymbol{p}}}_{I+1}$ が得られる.

$$
\tilde{\overline{\boldsymbol{p}}}_{I+1}=\tilde{\overline{\boldsymbol{p}}}_{M}+\Delta \tilde{\overline{\boldsymbol{p}}}_{M}+\boldsymbol{H}^{T} \overline{\boldsymbol{p}}_{r}
$$

すると, 不つり合いカベクトル $\tilde{\bar{r}}_{I+1}$ は次式で与えられ る.

$$
\begin{aligned}
\tilde{\overline{\boldsymbol{r}}}_{I+1} & =\tilde{\overline{\boldsymbol{p}}}_{M+1}+\tilde{\overline{\boldsymbol{p}}}_{r, 0}-\tilde{\overline{\boldsymbol{p}}}_{\boldsymbol{I}+1} \ldots \ldots \ldots \ldots \ldots \ldots \ldots(36) \ldots \ldots \ldots \ldots \ldots \\
& =\tilde{\overline{\boldsymbol{p}}}_{M+1}-\left\{\tilde{\overline{\boldsymbol{p}}}_{M}+\Delta \tilde{\overline{\boldsymbol{p}}}_{\boldsymbol{M}}+\boldsymbol{H}^{\boldsymbol{T}} \cdot\left(\overline{\boldsymbol{p}}_{r}-\overline{\boldsymbol{p}}_{r, 0}\right)\right\}
\end{aligned}
$$

ここで, $\tilde{\overline{\boldsymbol{p}}}_{M+1}$ は第 $\mathrm{M}+1$ 荷重段階において外力とし て与えた一般化力ベクトルであり， $\overline{\boldsymbol{p}}_{r, 0}$ は，文献 14) で述べた仮想の節点外力ベクトルである.

\section{（3） 柱要素の变位関数および剛性マトリックス} の計算

変位関数として次のものを用いる.

$$
\left\{\text { 軸方向変位 } u=\alpha_{1}+\alpha_{2} x \ldots \ldots \ldots \ldots \ldots \ldots . . .(38)\right.
$$$$
\text { たわみ } w=\alpha_{3}+\alpha_{4} x+\alpha_{5} x^{2}+\alpha_{6} x^{3} \cdot \cdot(39)
$$

また, 柱要素の場合も, 補剛材の高さ方向への塑性の 広がりを考慮できるように，板要素の場合と同様に，層 割りを行って剛性マトリックスの計算を行っている.

\section{4. 数值計算例およびその考察}

\section{（1） 周辺単純支持の圧縮板}

文献 14）と同様，図一5 に示すような周辺単純支持の 一方向圧縮板を解析例とする.

\section{a) マトリックス $\boldsymbol{H}_{k}$}

面外挙動に関する周辺の境界条件は,

$$
\begin{aligned}
& \text { 辺 } X= \pm a / 2 \text { および辺 } Y=0, b \text { において } \Delta W=0 \\
& \text { 辺 } X= \pm a / 2 \text { に扔いて } \partial^{2} \Delta W / \partial X^{2}=0 \\
& \text { 辺 } Y=0, b \text { において } \partial^{2} \Delta W / \partial Y^{2}=0
\end{aligned}
$$

この境界条件を満足し,さらに, たわみの対称性を考慮 して, 以下に示す関数を板のたわみ波形に用いる.

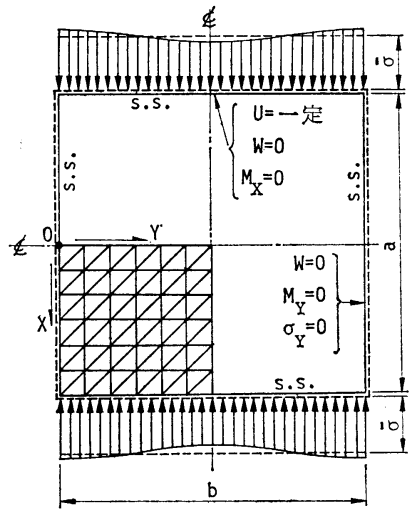

図一5 周辺単純支持の圧縮板

$$
\Delta W=\sum_{m=1,3,5 \ldots .}^{M} \cdot \sum_{n=1,3,5 \ldots}^{N} \Delta W_{m n} \cdot \cos \frac{m \pi X}{a} \cdot \sin \frac{n \pi Y}{b}
$$

すると，式（24）に示したマトリックス $\boldsymbol{H}_{k}$ は次のよう になる.

$$
\boldsymbol{H}_{k}=\left[\begin{array}{cccc}
\boldsymbol{I} & \mathbf{0} & \mathbf{0} & \mathbf{0} \\
\mathbf{0} & \mathbf{0} & \mathbf{0} & \boldsymbol{H}_{w i} \\
\mathbf{0} & \boldsymbol{I} & \mathbf{0} & \mathbf{0} \\
\mathbf{0} & \mathbf{0} & \mathbf{0} & \boldsymbol{H}_{w j} \\
\mathbf{0} & 0 & \boldsymbol{I} & 0 \\
0 & 0 & 0 & \boldsymbol{H}_{w k}
\end{array}\right]
$$

ここで, $\boldsymbol{I}$ は $2 \times 2$ の単位マトリックス, $\boldsymbol{H}_{\boldsymbol{w}}$ は板要素 $k$ の節点 $i$ (全体座標 $X_{i}, Y_{i}$ ) の面外変位増分べクト ル $\Delta \boldsymbol{w}_{i}$ と一般化たわみ増分ベクトル $\Delta \tilde{\boldsymbol{w}}$ を関係づける マトリックスである.すなわち，

$$
\Delta \boldsymbol{w}_{i}=\boldsymbol{H}_{w i} \cdot \Delta \tilde{\boldsymbol{w}}
$$

ここに,

$$
\begin{array}{r}
\Delta \boldsymbol{w}_{i}=\left\{\Delta W_{i} ; \Delta \theta_{X i} ; \Delta \theta_{Y i}\right\} \ldots \ldots \ldots \ldots \ldots \ldots \\
\Delta \tilde{\boldsymbol{w}}=\left\{\Delta W_{11} ; \Delta W_{13} ; \Delta W_{31} ; \Delta W_{33} ; \cdots ;\right. \\
\left.\quad \Delta W_{m n} ; \cdots\right\} \ldots \ldots \ldots \ldots \ldots \ldots \ldots \ldots \ldots \ldots \ldots \ldots \ldots \ldots \ldots \ldots \ldots
\end{array}
$$

$$
\boldsymbol{H}_{w i}=\left[\begin{array}{lllllll}
H_{111} & H_{113} & H_{131} & H_{133} & \cdots & H_{1 m n} & \cdots \\
H_{211} & H_{213} & H_{231} & H_{233} & \cdots & H_{2 m n} & \cdots \\
H_{311} & H_{313} & H_{331} & H_{333} & \cdots & H_{3 m n} & \cdots
\end{array}\right]
$$

$$
\begin{aligned}
& H_{1 m n}=\cos a_{m} X_{i} \cdot \sin b_{n} Y_{i} \\
& H_{2 m n}=-b_{n} \cdot \cos a_{m} X_{i} \cdot \cos b_{n} Y_{i} \\
& H_{3 m n}=-a_{m} \cdot \sin a_{m} X_{i} \cdot \sin b_{n} Y_{i}
\end{aligned}
$$

$a_{m}=m \pi / a, b_{n}=n \pi / b$.

$\boldsymbol{H}_{w j}, \boldsymbol{H}_{w k}$ についても同様である.

b) 連立方程式（28）の解法

式 (28) の剛性マトリックス $\tilde{K}_{I}$ においては 図一6(a) に示す薄墨部分のところ以外の要素は 0 である. 対角線 付近のバンド部分 (1) は板の面内剛性に関する要素であ る. 右下隅角部 (3) は面外剛性に関する要素であり, 外 側のバンド部分 $(2)$ は両者の連成効果に関する要素であ 


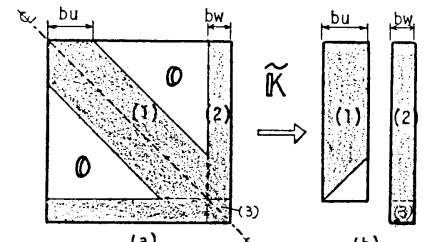

(a)

(b)

図一6 $\tilde{K}$ の記憶方法

る. [対称性を利用して, このマトリックス $\tilde{\boldsymbol{K}}$ の上半分 を 図一6(b) に示すようにバンド状に記憶させ, コレス キー法により連立方程式（28）を解いた.

c） 解析に用いた初期不整

任意の波形の初期たわみを含む場合も解析可能である が,ここでは文献 14）と同様に, 次式で示す初期たわみ 波形を仮定した.

$$
W_{0}=\bar{W}_{0} \cdot \cos \pi X / a \cdot \sin \pi Y / b, \bar{W}_{0}=0.1 \cdot t
$$

$t:$ 板厚. 圧縮板の数值解析では残留応力を 考慮しなか った.

d) 解析結果とその考察

(1) たわみ波形の項数 (NWN) と精度の関係

解析結果を図一7 と表一1 に示す. これらの図表にお けるパラメーター NWN は式（41）に示したたわみ波 形の打切り項数である.ただし，それぞれのたわみ波形 は $\Delta W_{11}, \Delta W_{13}, \Delta W_{31}, \Delta W_{33}, \Delta W_{15}, \Delta W_{51}$ の順に並んで いる.幅厚比パラメーター $R\left(=b / t \sqrt{\sigma_{y} / E \cdot 12\left(1-\nu^{2}\right) / \pi^{2} k}\right)$ が 1.34 と比較的大きい板に対して, NWN を $1,3,4$,

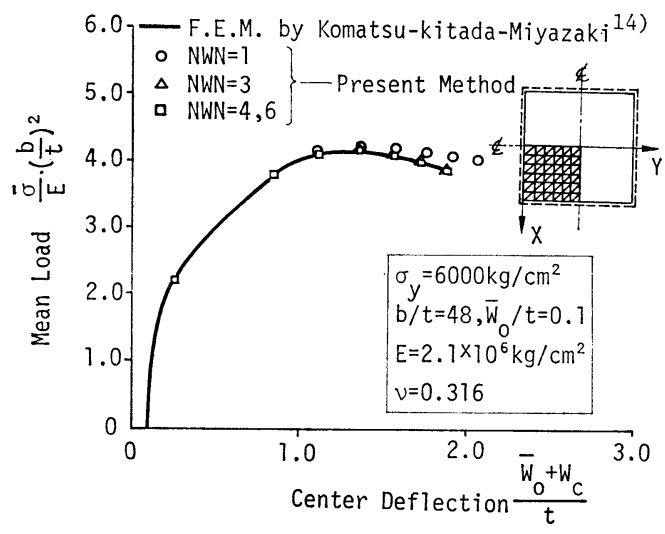

図一7 平均圧縮応力度と中央たわみの関係 $(R=1.34)$

表一1 級数の項数と精度の関係

\begin{tabular}{|c|c|c|c|c|c|c|}
\hline & NWN & $\Delta W_{i, j}$ & $\bar{\sigma}_{m}\left(\mathrm{~kg} / \mathrm{cm}^{2}\right)$ & Error (\%) & $\bar{\sigma} m\left(\mathrm{~kg} / \mathrm{cm}^{2}\right)$ & Error (\%) \\
\hline F.E.M. (1) & & & 3782.0 & - & 2327.4 & - \\
\hline & 1 & $11(i=1, j=1)$ & 3875.8 & 2.48 & 2334.9 & 0.32 \\
\hline Present & 3 & $11,13,31$ & 3807.2 & 0.66 & 2332.9 & 0.24 \\
\hline Method & 4 & $11,13,31,33$ & 3800.0 & 0.48 & 2332.2 & 0.21 \\
\hline & 6 & $11,13,31,33,15,51$ & 3799.1 & 0.45 & 2332.2 & 0.21 \\
\hline \multicolumn{3}{|c|}{$\bar{\sigma}_{m}:$ 平均圧縮応力度の最大値 } & \multicolumn{2}{|c|}{$\begin{array}{l}\sigma_{y}=6000 \mathrm{~kg} / \mathrm{cm}^{2} \\
b / t=48.0 \quad \bar{W}_{0} / t=0.1\end{array}$} & \multicolumn{2}{|c|}{$\begin{array}{l}\sigma_{y}=2400 \mathrm{~kg} / \mathrm{cm}^{2}, \\
R=0.71 \\
b / t=40.0 \quad \bar{W}_{0} / t=0.1\end{array}$} \\
\hline
\end{tabular}

6 と変化させた場合の平均圧縮応力度 $\bar{\sigma}$ と板中央のたわ み $W_{c}$ の関係を図一7に示した. 同図には, 文献 14)の 有限要素法のみによる解析結果をも示している. この有 限要素法のみによる解はすでに 文献 14) で Coan の厳 密解と比較し, その精度の検証を行ったものである. $\mathrm{NWN}=3$ とすれば, 本法による解析結果は完全に有限 要素法のみの結果に一致することが図一7 からわかる. 表一1 より, 最大平均応力度 $\bar{\sigma}_{m}$ も, NWN が 3 以上 であれば, 有限要素法のみの結果と比較して, その誤差 は $1 \%$ 以下になることがわかる. 次に, $R$ が 0.71 と比 較的小さい板に対する同様な解析結果を 表一1 の右側の 欄に示す.この場合, 本法による解はさらに精度がよく NWN が 1 で有限要素法による解に十分収束している ことがわかる。

\section{表一2 1 回の反復計算に必要な計算時間 (CPU タイム) （要素分割数 $N=6$, 層数 $N T=8$ )}
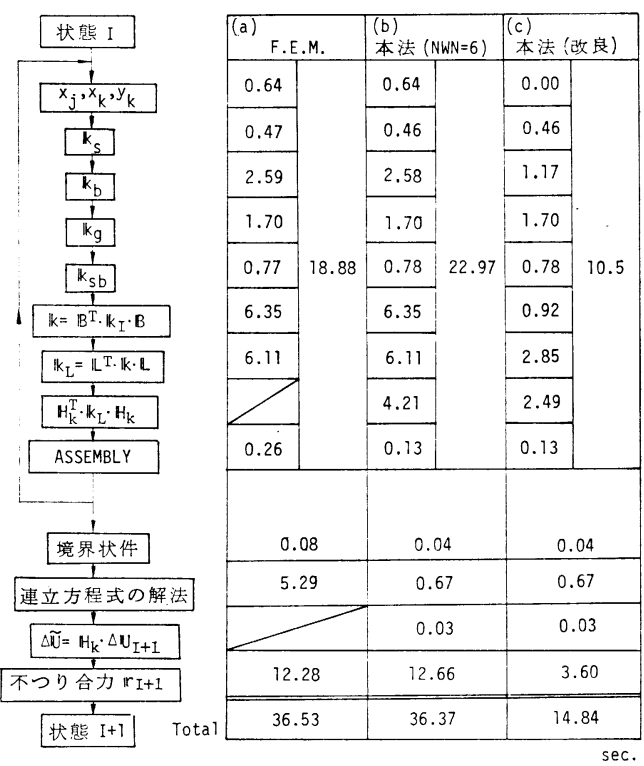

(2) 計算時間について

有限要素法のみを用いた場合と本法を用いた場合のそ れぞれについて, 第 I 段階から第 I+1 段階に至る 1 回 の反復計算における各計算過程（各サブルーチン）に必 要な $\mathrm{CPU}$ タイムを 表一2 に示す. この表より以下の ことが明らかになった。

i ） 本法を用いることにより解析モ デルの自由度が有限要素法のみの場合に 比して約 $40 \%$ に低減されている.した がって,連立方程式の解法に必要な $\mathrm{CPU}$ タイムは, 5.3 秒から 0.67 秒へときわ めて短くなっていることがわかる.

ii）しかし，この程度の構造物では， 
1 回の反復計算に必要な $\mathrm{CPU}$ タイムの中に占める連立 方程式の解法に要する CPU タイムの割合は, 有限要素 法のみの場合約 $14 \%$ にしかすぎない. すなわち, 全体 系の連立一次方程式を解くより，それを組み立てる作業 の方にかなりの時間を要していることがわかる.

iii） 剛性マトリックスの計算によく出てくる $\boldsymbol{A}^{T} \cdot \boldsymbol{X}$. $\boldsymbol{A}$ といら形のマトリックスの掛け算にはかなりの計算時 間を要するということがわかった。

iv）さらに, $\boldsymbol{A}^{T} \cdot \boldsymbol{X} \cdot \boldsymbol{A}$ といら形のマトリックスの掛 け算において, マトリックス $\boldsymbol{A}, \boldsymbol{X}$ に 0 要素が多い場 合には, あらかじめ手計算で数式化しておくと計算時間 がかなり短縮できることがわかった，たとえば， $B^{T}$. $k_{I} \cdot B, L^{T} \cdot k \cdot L$ および $H_{k}{ }^{T} \cdot k_{L} \cdot H_{k}$ の計算においてこ の処理を行うことにより表一2の (c) 欄（改良）に示す ように CPU タイムがかなり減少でき, 当初 1 回の反復 計算に 36.4 秒かかっていたのに, この処理を行った後 は 14.8 秒となった. 合計して, 反復計算 1 回ごとに, 36.4 秒から 14.8 秒と約 $60 \%$ の CPU タイムの節減 が達成できた。 なお，この圧縮板の計算は大阪大学大型 計算機センター NEAC シリーズ $2200 \mathrm{~N}-700$ を用いて 行った.

\section{（2）周辺単純支持の圧縮補剛板}

a） 解析モデル

図一8 に示すような縦リブ 2 本を有する周辺単純支持

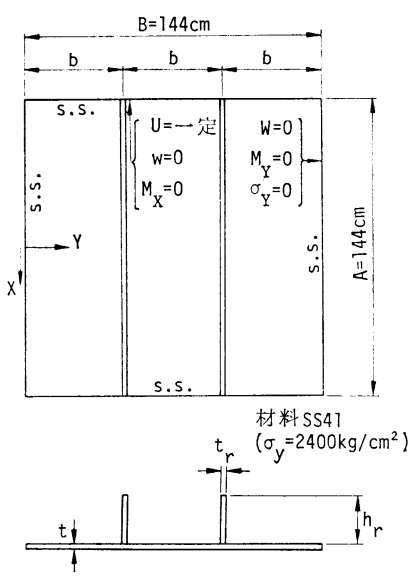

図一8 補剛板の解析モデル

表一3 補剛板モデルの寸法諸元

\begin{tabular}{c|c|c|c|c|c|c|c}
\hline 供試体 & $R$ & $\gamma / \gamma_{\mathrm{N}}$ & $A$ & $B$ & $t$ & $h_{r}$ & $t_{r}$ \\
\hline$M 1$ & 0.7 & 1.0 & 1440 & 1440 & 12.0 & 90.065 & 12.0 \\
\hline M 2 & 0.7 & 5.0 & 1440 & 1440 & 12.0 & 134.68 & 17.944 \\
\hline M 2 & 1.3 & $1.0^{*}$ & 1440 & 1440 & 6.56 & 56.538 & 7.54 \\
\hline M 3 & 1.3 & $5.0^{\star}$ & 1440 & 1440 & 6.56 & 84.549 & 11.273 \\
\hline \multicolumn{3}{c|}{$: \gamma / \gamma^{*}$} & \multicolumn{5}{c}{ (長さの単位 mm) }
\end{tabular}

の圧縮板を解析例に取り上げ る. 板厚 $t_{r}$ とリブの高さ $h_{r}$ を表一3に示すように変化さ せた 4 種類の解析モデルを考 えた.すなわち,幅厚比パラメ ーター $R$ が道路橋示方書 (以 下，道示という）で規定する 限界值 0.7 および $R$ が大き く 1.3 の 2 ケース,さらに 補剛材の剛比については道示 （あるいは DIN 4114）で定 める必要最小剛比 $\gamma_{N}$ (ある いは $\left.r^{*}\right)$ の 1 倍ないし 5 倍 の 2 ケースとした．載荷辺の 板パネル中央面に一様相対圧 縮変位を導入することによっ て圧縮荷重を与えた.

b) メッシュ分割

図一9に示すように全体の $1 / 4$ 部分を $9 \times 9$ の細かいメ ッシュ分割と $6 \times 6$ の若干粗 いメッシュ分割にした 2 種類 の離散化モデルについて解析 を行った. 縦リブが曲げに対 して比較的剛な場合には, 縦 リブ間の板パネルのたわみが 卓越して発生する.この場合 には，板パネルでは文献 14） の圧縮板の挙動と類似してく

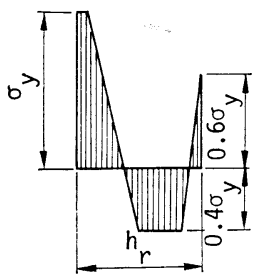

補剛材部の残留応力

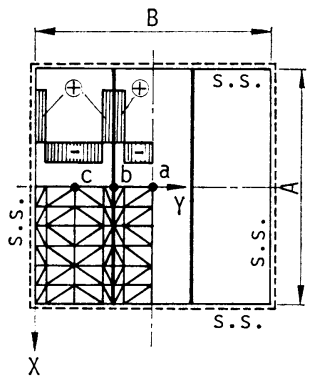
$9 \times 9 \times ッ シ ュ$ 分割

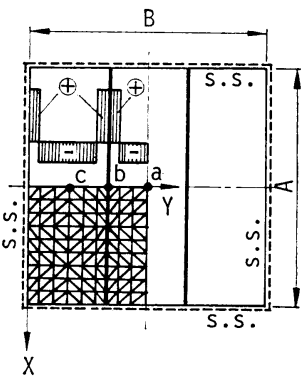
$9 \times 9 \times ッ シ ュ$ 分割

図一9メッシュ分割 るので, 同文献を参考にして, リブ間を 6 分割すること にした.リブが弾性曲げを生じる場合には, 補剛板の全 体的なたわみが卓越してくるため, それよりも粗い分割 でもよいものと思われる. 平面三角形要素の層分割数は 文献 14)により 4 とした. 補剛材部分に相当する柱要素 の層分割数は 6 とした. 6 層と 10 層の場合の結果を比 較したが有意な差は認められなかった。

c） 解析に用いたたわみ波形

式（41）に示されるたわみ波形を用いた. 級数の項数 は, 最大 $m=5, n=5$ の合計 25 項までを考慮すること にした.

d）初期たわみ抢よび残留応力度

初期たわみについては，図一10（a）の全体的な 初期 たわみモード $\left(W_{g_{0}}\right)$ と，図一10 (b) 汇示すような板パ ネルの局部的な初期たわみモード $\left(W_{l g}\right)$ の和として補 剛板各節点の初期たわみを与えた.すなわち,

$$
\begin{aligned}
& W_{0}=W_{g 0}+W_{l 0} \\
& W_{g 0}=\delta \cdot f(X, Y)
\end{aligned}
$$




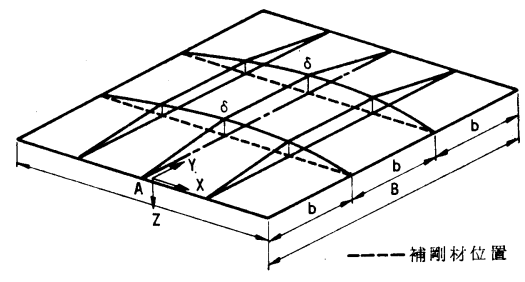

（a）全体的初期たわみモード W

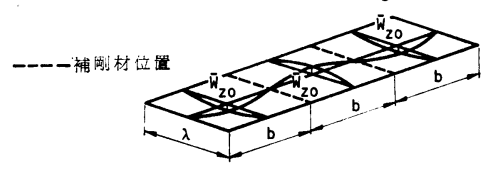

(b) 板パネルの局部的初期たわみモード $W_{10}$

図一10補网板の初期たわみモード

$$
f(X, Y)= \begin{cases}Y / b \cdot \cos (\pi X / A) & (0 \leq Y \leq b) \\ \cos (\pi X / A) & (b \leq Y \leq 2 b) \\ (B-Y) / b \cdot \cos (\pi X / A) & (2 b \leq Y \leq B)\end{cases}
$$

$W_{l 0}=\bar{W}_{l 0} \cdot \cos (\pi X / \lambda) \cdot \sin (\pi Y / b)$,

$$
\lambda=b \text { (正方形パネル) }
$$

$\delta$ は補剛材の最大初期たわみでその符号はたわみが補剛 材側に変形している場合を正とする. 今回の解析例では 道示の規定限界值を準用するといら意味で,

$$
\delta=A / 1000, \bar{W}_{l 0}=b / 150
$$

とした.

残留応力分布については, 板パネルおよび補剛材部の 平均残留圧縮応力度 $\bar{\sigma}_{r c}, \bar{\sigma}_{r c, r}$ をともに $-0.4 \sigma_{y}$, 残 留引張り応力度 $\sigma_{r t}$ を降伏点 $\sigma_{y}$ とし, 自己平衡条件を 考虑して，図一9 に示すような分布形とした.

e) 解析結果とその考察

(1) 精度について

i ）本法 と有限要素法 との比較

級数の項数 NWN 25 項に取り，解析モデル M1 について, 図一9 に示すよ

$$
\begin{aligned}
& \text { 表一4 M1 モデルの解析 } \\
& \text { 結果 }\left(\bar{\sigma}_{m} / \sigma_{y}\right)
\end{aligned}
$$

\begin{tabular}{|c|c|c|c|c|}
\hline モデル & $\begin{array}{ll}M=0 . \\
M / Y_{N}\end{array}$ & $\begin{array}{c}M 2=0 \\
\gamma / \gamma_{N}\end{array}$ & $M 3 \begin{array}{c}R=1.3 \\
\gamma / \gamma^{*=1}\end{array}$ & M4 $\begin{array}{c}R=1.3 \\
\gamma / \gamma^{\star}=5\end{array}$ \\
\hline (1) FEM & 0.697 & 0.733 & 0.375 & 0.548 \\
\hline (2)本法(NUN=25) & 0.700 & 0.740 & 0.377 & 0.550 \\
\hline (2) - (1) $) /($ (1) & $0.4 \%$ & $1.0 \%$ & $0.5 \%$ & $1,0 \%$ \\
\hline
\end{tabular}

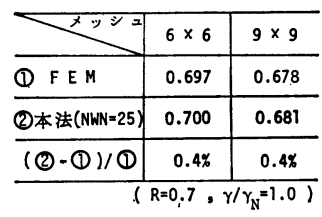

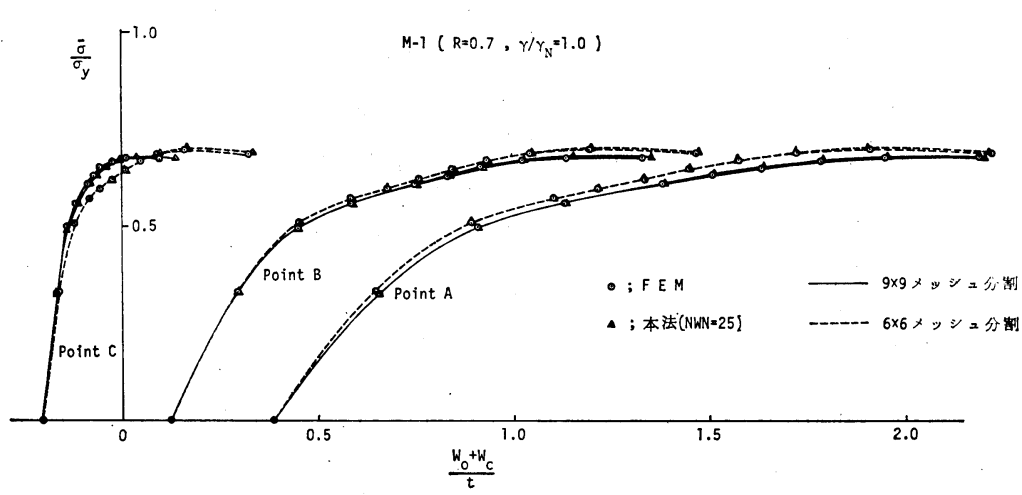

\begin{tabular}{|c|c|c|c|c|}
\hline モデル & $\begin{array}{c}M-1 \\
(R=0.7) \\
\left(\gamma / \gamma_{N}=1\right)\end{array}$ & $\begin{array}{c}M-2 \\
(R=0.7) \\
\left(\gamma / \gamma_{N}=5\right)\end{array}$ & $\begin{array}{c}M-3 \\
(R=1.3) \\
\left(\gamma / \gamma^{*}=1\right)\end{array}$ & $\begin{array}{c}M-4 \\
(R=1,3) \\
\left(\gamma / \gamma^{*}=5\right)\end{array}$ \\
\hline (1) $6 \times 6$ 分割 & 0.700 . & 0.740 & 0.377 & 0.550 \\
\hline (2) $9 \times 9$ 分割 & 0.681 & 0.700 & 0.360 & 0.501 \\
\hline$($ (1) - (2) )/(2) & $2.8 \%$ & $5.7 \%$ & $4.7 \%$ & $9.8 \%$ \\
\hline
\end{tabular}

図-11 F.E.M. と本法との比交
衰一5 $\overline{\boldsymbol{\sigma}}_{m} / \boldsymbol{\sigma}_{y}$ (F.E.M. と本法の比較)

表一6 $\quad \overline{\boldsymbol{\sigma}}_{m} / \boldsymbol{\sigma}_{y}$ (メッシュ分割と精度の関係)

うな 2 種類のメッシュ分割を用いた解析結果を 図一11 と表一 4 に示す. 表一 4 には最大平均圧縮応力度 $\bar{\sigma}_{m}$ を 降伏点 $\sigma_{y}$ で無次元化した值 $\bar{\sigma}_{m} / \sigma_{y}$ が示されている.

これらの図表より，有限要素のメッシュ分割数にかかわ らず，級数の項数が十分であれば，本法による解析結果 は有限要素法のみを適用した場合の結果に収束している ことがわかる.

また, 表一5 には, 幅厚比パラメーター $R$ および補 䣓材㣚比 $r$ を変化させた 4 つの解析モデルについて, 6 $\times 6$ のメッシュ分割を用いた解析結果を, 本法と有限要 素法のみを用いた場合とを比較して示してある. この表 より, 級数の項数 NWN を多く（いまの場合 25 項） 取れば, 本法による結果は有限要素法のみの解に収束す ることがわかる。

ii ) メッシュ分割数と精度の関係

$\mathrm{NWN}=25$ とし, メッシュ分割を $6 \times 6$ と $9 \times 9$ の 2 通 りについて, 本法を用いて解析した結果を 表一6 に示 す.この表より以下のことがわかる. 幅厚比パラメータ 一 $R$ が 0.7 で補剛材の棡比 $r$ が道示の最小剛比 $r_{N}$ に等しい解析モデル M1 では $6 \times 6$ メッシュ分割を用 いることによる誤差は $2.8 \%$ と小さい. ところが, $R$ が 0.7 より大きくなるにつれて, また, 剛比 $r$ が $r_{N}$ あるいは $r^{*}$ に比して大きくなるにつれて, $6 \times 6$ ッシュ分割を用いること による誤差は大きくなってくる ことがわかる.すなわち， $R \leq$ $0.7, r / r_{N} \fallingdotseq 1$ なる 全体変形の 卓越する補剛板では $6 \times 6$ メッ シュ分割でよい.それに対して $R \leq 0.7, r / r_{N}>1$ および $R>$ $0.7, r / r_{N} \geq 1$ あるいい $r / r^{*} \geq 1$ なる全体変形と局部変形がとも 
表一7 柾限状㮩でのたわみモードの保数の比 $\rho\left(\rho=\left|W_{m n} / W_{11}\right|\right)$

(a) $M 1\left(R=0.7, \gamma / \gamma_{N}=1\right)$

\begin{tabular}{|c|c|c|c|c|c|}
\hline$n$ & 1 & 3 & 5 & 7 & 9 \\
\hline 1 & 1.000 & 0.020 & 0.021 & 0.006 & 0.000 \\
\hline 3 & 0.026 & 0.301 & 0.012 & 0.001 & 0.002 \\
\hline 5 & 0.002 & 0.008 & 0.001 & 0.005 & 0.005 \\
\hline 7 & 0.003 & 0.001 & 0.003 & 0.002 & 0.000 \\
\hline 9 & 0.000 & 0.000 & 0.000 & 0.000 & 0.001 \\
\hline
\end{tabular}

(c) $M 3\left(R=1.3, \gamma / \gamma^{*}=1\right)$

\begin{tabular}{|c|c|c|c|c|c|}
\hline$m^{n}$ & 1 & 3 & 5 & 7 & 9 \\
\hline 1 & 1.000 & 0.048 & 0.021 & 0.005 & 0.001 \\
\hline 3 & 0.037 & 0.344 & 0.031 & 0.004 & 0.003 \\
\hline 5 & 0.032 & 0.013 & 0.017 & 0.014 & 0.003 \\
\hline 7 & 0.016 & 0.013 & 0.011 & 0.003 & 0.000 \\
\hline 9 & 0.001 & 0.000 & 0.002 & 0.001 & 0.001 \\
\hline
\end{tabular}

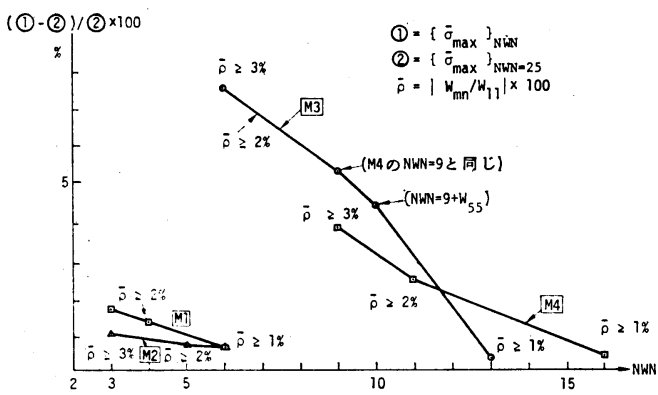

图一12 NWN と精度の関係

に問題となるような補剛板では $9 \times 9$ メッシュ分割を用 いるのがよい.

iii） 級数の項数 NWN と精度の関係

極限状態における各たわみモードの係数 $W_{m n}$ を係数 $W_{11}$ で無次元化し，その絶対值 $\rho$ を表一7 に示す. 解 析に用いる NWN の項数として， $\rho \geq 1 \%$ を满足する 波形を取ると, 解析モデル M 1, M 2 では $\mathrm{NWN}=6$ と なり, M 3 では $\mathrm{NWN}=13, \mathrm{M} 4$ では $\mathrm{NWN=16}$ とな る.この NWN を用いて解析した場合の最大平均応力 度 $\bar{\sigma}_{m}$ は, $N W N=25$ とした場合の結果に比して, そ の誤差はすべて 0.6\% 以下に収まっていることが図一12 からわかる.この図には，NWN を徐々に少なくして いった場合の結果をも示している. 図より，2本の縦補 剖材を有する縦横比 1 の周辺単純支持板に一方向の一様 圧縮力が作用する場合の解析を行ううえで, 以下のこと が結論できる. 幅厚比パラメーター $R$ が 0.7 以下で, 補剛材剛比 $r / r_{N}$ が 1 5 の範囲にある補剛板の場合,

(b) $M 2\left(R=0.7, \gamma / \gamma_{N}=5\right)$

\begin{tabular}{|c|c|c|c|c|c|}
\hline$m^{n}$ & 1 & 3 & 5 & 7 & 9 \\
\hline 1 & 1.000 & 0.010 & 0.025 & 0.003 & 0.001 \\
\hline 3 & 0.037 & 0.702 & 0.015 & 0.000 & 0.002 \\
\hline 5 & 0.004 & 0.028 & 0.006 & 0.007 & 0.005 \\
\hline 7 & 0.002 & 0.000 & 0.002 & 0.002 & 0.000 \\
\hline 9 & 0.001 & 0.004 & 0.001 & 0.000 & 0.006 \\
\hline
\end{tabular}

(d) $M 4\left(R=1.3, \gamma / \gamma^{*}=5\right)$

\begin{tabular}{|c|c|c|c|c|c|}
\hline $\mathrm{m}$ & 1 & 3 & 5 & 7 & 9 \\
\hline 1 & 1.000 & 0.050 & 0.030 & 0.006 & 0.001 \\
\hline 3 & 0.037 & 0.673 & 0.040 & 0.017 & 0.018 \\
\hline 5 & 0.038 & 0.035 & 0.018 & 0.025 & 0.002 \\
\hline 7 & 0.031 & 0.019 & 0.024 & 0.006 & 0.002 \\
\hline 9 & 0.003 & 0.012 & 0.005 & 0.003 & 0.005 \\
\hline
\end{tabular}

解析に用いる級数を $W_{11}, W_{33}, W_{31}$ の 3 項, $R$ が 0.7 より大きく, $r / r^{*}$ が $1 \sim 5$ の範囲内にある 補剛板の場 合, 解析に用いる 級数を $W_{11}, W_{13}, W_{33}, W_{31}, W_{15}$, $W_{35}, W_{55}, W_{53}, W_{51}, W_{57}, W_{75}, W_{73}, W_{71}$ の 13 項に すれば，項数を減らしたことによる誤差は 296 以下に 収まる。

(2) 記憶容量

表一8 に, 全体系の剛性 マトリックス $\boldsymbol{K}_{\boldsymbol{I}}$ を記憶す るのに必要なコンピュータ 一のワード数を示す. 本法 により大幅な記憶容量の節 減が期待できることがわか る.

(3) 計算時間について

表一9 に 1 回の反復計算（状態 I から I+1 への計算）

表一91 回の反得計算に必要な㖕算時间(CPUタイム)

\begin{tabular}{c|c|c|c|c|c|c}
\hline & FEM & \multicolumn{5}{|c}{ 本法 } \\
\cline { 3 - 7 }$x * y=$ & NWN=3 & NWN=6 & NWN=9 & NWN-13 & NWN=25 \\
\hline $6 \times 6$ & 1.8 & 1.4 & - & 1.8 & - & 2.7 \\
\hline $9 \times 9$ & 4.7 & 3.2 & 3.5 & 3.9 & 4.3 & 6.2 \\
\hline
\end{tabular}

表一10 解析に必要なメッシュ分割および政数の 項数 NWN (縦横比 1, 縦補剛材 2 本)

\begin{tabular}{c|c|c}
\hline$\gamma$ & $R \leq 0.7$ & $0.7<R \leq 1.3$ \\
\hline$\gamma / \gamma_{N}=1$ & $6 \times 6 \times ッ *=$ & $9 \times 9 \times ッ シ=$ \\
$\gamma / \gamma^{*}=1$ & $N W N=3$ & $N W N=13$ \\
\hline $1<\frac{\gamma}{\gamma_{N}} \leq 5$ & $9 \times 9 \times ッ *=$ & $9 \times 9 \times ッ シ=$ \\
$1<\frac{\gamma}{\gamma^{*}} \leq 5$ & $N W N=3$ & NWN=13 \\
\hline
\end{tabular}




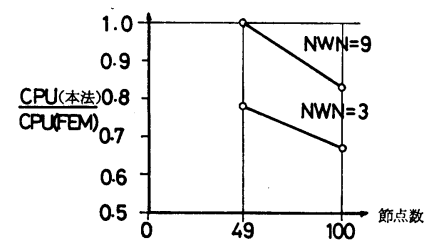

図-131 回の反径計算に必要な CPU タイムと節点数の関係

に必要な CPU タイムを示す. いままでの考察をまとめ ると, 解析に必要なメッシュ 分割と級数の項数 NWN は表一10 のようになる. 表一9 と表一10 を比較すると， $\mathrm{NWN}=13$ で解析を行ら必要がある $R>0.7$ なる補剛 板では, 本法は有限要素法のみを用いる方法に比較し て, 計算時間については大差ないことがわかる. しか し，わが国の実橋で普通によく用いられる $R \leq 0.7$ な る補剛板では $\mathrm{NWN}=3$ で解析してよく, 計算時間の節 減も期待できることがわかる. また, 図一13 に示すよ うに, F.E.M. の自由度が大きくなるにつれて, 計算時 間についても, 一般的に, 本法が有力な武器になること が推測される. なお, 補剛板の計算については, 京都大 学大型計算機センターの FACOM・M-190 を用いた.

\section{5. 実験値との比較}

以下のように, 本法による結果と実験結果を比較する ことにより, 本解析理論で用いた種々の力学的仮定の合 理性の検証を行った.

\section{（1）対象とした実験供試体とその挙動}

文献 17) に示されている実験結果のらちで, 縦リブの みを有し，その剛比が道示 の基準值に等しい供試体 L 2 D 1 の実験結果と 本解 析結果の比較を行う. 供試 体 L 2 D 1 の断面寸法を図 -14 に示す. 供試体材料 は, 実測板厚 $10.6 \mathrm{~mm}$ の SS 41 で, その実測降伏点 は $2680 \mathrm{~kg} / \mathrm{cm}^{2}$ である. 圧縮力は, 板パネルの中央 面に一様相対圧縮変位とし て与えられ，面外境界条件 に対しては周辺単純支持, 面内の境界条件に対しては 側辺拘束なしという条件で 実験が行われた，供試体 は，縦方向および横方向に

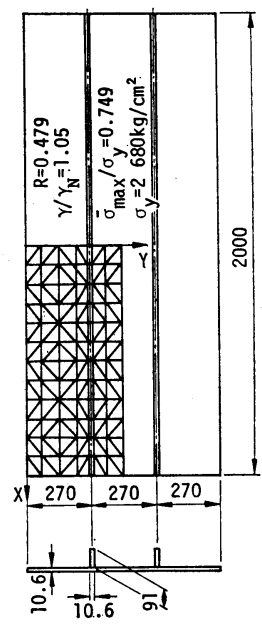

図一14 供試体 L 2 D 1 の寸法锗元と解 析モテル
大きな半波形のたわみが卓越して極限状態に至った. そ の極限強度 $\bar{\sigma}_{\max } / \sigma_{y}$ は 0.749 となっている. 供試体が 極限状態を通過しても補剛材間の板パネルの局部たわみ および補剛材の横倒れ局部変形は観察からは明白に認め られなかった.

\section{（2） 解析モデル}

a) モデル化

形状の対称性を利用して, 供試体の $1 / 4$ を取り出し解 析を行った. 幅厚比パラメーター $R$ が 0.479 であり, $r / r_{N}=1.0$ であるので, 4. (2) e) の結論を参考にして, 解析は $12 \times 6$ のメッシュ分割で $\mathrm{NWN}=6\left(W_{11}, W_{13}\right.$, $\left.W_{33}, W_{31}, W_{15}, W_{35}\right)$ として行った.

b）残留応力および初期たわみ

実験では, 全体的な半波形のたわみすなわち $W_{11}$ モー ドのみが卓越していたので, 解析でも $W_{11}$ モードに対応 する初期たわみ $W_{0}$ のみを考慮することにした．実測 した補剛材の初期たわみを 3 角級数にあてはめ, それを 基に以下のように初期たわみ波形を仮定した.

$$
W_{0}=0.139 \cdot t \cdot \cos (\pi X / 200) \cdot \sin (\pi Y / 81)
$$

また, 残留応力については, 今回の実測值に最もよく 適合する以下の諸量を用いて, 文献 15) の式 (1)〜 (13) に従って分布形を決定した.

$$
\bar{\sigma}_{r c} / \sigma_{y}=-0.41, \sigma_{r t} / \sigma_{y}=1.0, \bar{\sigma}_{r c, r} / \sigma_{y}=-0.52,
$$

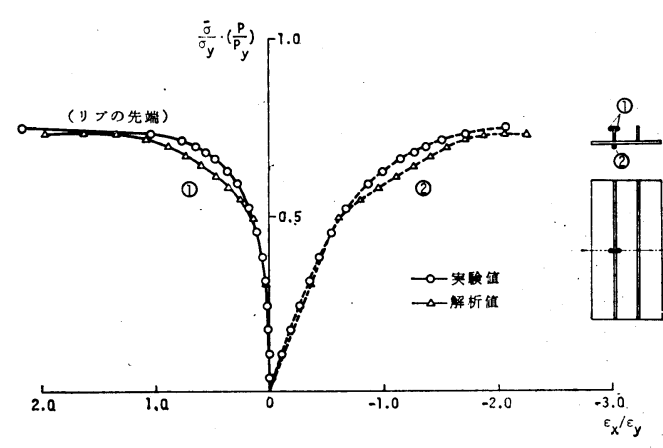

図一15解析值と实験怵との比較 $\left(\bar{\sigma} / \sigma_{y}-\varepsilon_{x} / \varepsilon_{y}\right)$

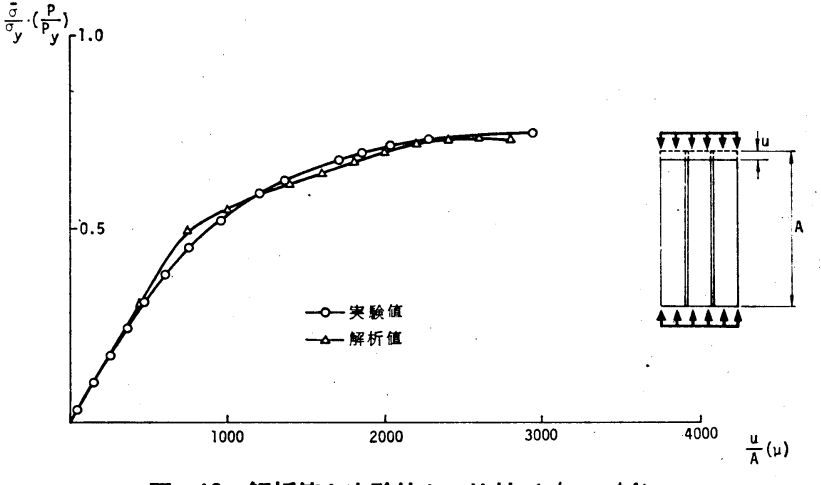

図一16 解析倠と実験做との比較 $\left(\bar{\sigma} / \sigma_{y}-u / A\right)$ 


$$
\sigma_{r, r} / \sigma_{y}=0.35, \gamma_{s}=0.29, \gamma_{s s}=0.5, \gamma_{t}=1.0
$$

\section{（3）解析結果と実験結果との対比および考察}

a) 平均圧縮応力度と圧縮ひずみの関倸

解析ならびに実験から得られた平均圧縮応力度 $\bar{\sigma}$ と中 央断面における補剛材先端と付け根の軸方向ひずみ $\varepsilon_{x}$ の関係を，それぞれ，降伏点 $\sigma_{y}$ および降伏ひずみ $\varepsilon_{y}$ $\left(\sigma_{y} / E\right)$ で無次元化して 図一15 に示す. 解析結果と実 験結果はきわめて良好な一致を示している.さらに $\bar{\sigma} / \sigma_{y}$ と平均圧縮ひずみ $u / A(u$ : 圧縮変位) の関係を図一16 に示寸．雨者はきわめて良好な一致を示している.

\section{b) 極限強度}

無次元極限応力度 $\bar{\sigma}_{\max } / \sigma_{y}$ の実験值は 0.749 , 計算 值は 0.735 となった． $1.8 \%$ 低めの，すなわち，若干 安全側のきわめて良好な計算值を得た。

\section{6. 結論}

本論文で得られた結論のらちで, 補剛板の解析に関す るものをまとめると以下のとおりである.

（1）初期たわみと残留応力が共存する圧縮補剛板の 弾塑性解析に関して, 通常の有限要素法にモーダル・ア ナリシス的手法を導入した一解析手法を提示した。

（2）たわみ波形を有限項の級数で表わすことによ り, 本法による解は通常の有限要素法のみの解に収束す ることがわかった。

（3）実験值と対比することにより本法の妥当性を示 した.

（4）一般の単純支持長方形圧縮補剛板の解析におい ては, 本法では通常の有限要素法に比し, 構造系の自由 度を大幅に節減できることがわかった。

（5）また，本法によれば，幅厚比パラメーター $R \leq$ 0.7 で一様圧縮を受ける周辺単純支持の補剛板では, 計 算時間の節減も期待できる.

（6）縦リブ 2 本, 緹横比 1 で一様圧縮を受ける板に 本法を適用する場合， $R \leq 0.7$ で補剛材剛比 $r$ が道路 橋示方書の規準值 $\gamma_{N}$ 程度であれば, 有限要素のメッシ 二分割は $6 \times 6$, 用いる級数の項数は 3 で解析してよい. また， $R \leq 0.7$ で $1<r / r_{N} \leq 5$ なる補剛板では, $9 \times$ 9 メッシュ分割, 項数 $3,0.7<R \leq 1.3$ で $1 \leq r / r^{*} \leq$ 5 なる補剛板では $9 \times 9 \times ッ シ ュ$ 分割, 項数 13 で解析 を行えばよい。

さらに, 有限要素法による数值計算に関して, 以下の 付随的成果を得た。

（1）従来, 連立一次方程式の数值解析法による CPU タイムの低減について種々研究がなされている. しか し, 本研究の結果, 計算に必要な CPU タイムのうちで,
連立方程式の解法に要する $\mathrm{CPU}$ タイムの占める割合は わずかであることがわかった，それに比して，剛性マ下 リックスを組み立てる作業にかなりの時間を要すること がわかった。

（2）剛性マトリックスの計算によく出てくる $\boldsymbol{A}^{T}$. $\boldsymbol{X} \cdot \boldsymbol{A}$ という形のマトリックスの掛け算にはかなりの計 算時間を要することがわかった， $\boldsymbol{A}, \boldsymbol{X}$ に0 要素が多い 場合には，あらかじめ手計算で数式化しておくとかなり 計算時間が短縮できることがわかった。

\section{7. あとがき}

本論文の作成にあたり, 当時, 大阪大学大学院学生の 岡田純一氏（現在・住友金属工業（株））同じく奈良 敬 氏（現在・大阪大学工学部）にご協力いただいたことを 付記しここに感謝の意を表します.

\section{参 考 文 献}

1) Bilstein, W. : Beitrag zur Berechnung vorverformter, mit diskreten Längssteifen ausgesteifter, ausschließlich in Längsrichtung belasteter Rechteckplatten nach der nichtlinearen Beultheorie, Der Stahlbau, 7/1974, S. 193 $\sim 201$, Fortsetzung, 9/1974, S. 276 282.

2）岡村宏一・吉田公憲：大たわみ，および，リブの補剛を 考慮した長方形鋼板の弾塑性解析, 土木学会論文報告集, 第 196 号, pp. 29 43, 1971 年 12 月.

3）岡村宏一・吉田公憲：大たわみ，および，リブの補剛を 考慮した長方形鋼板の弾塑性曲げ座屈, 土木学会第 27 回 年次学術講演会概要集, I - 88, pp. 231 234，1972 年 10 月.

4）岡村宏一・吉田公憲：圧縮を受けるリブ付き鋼板の弾塑 性座屈, 昭和 49 年度土木学会関西支部年次学術講演会概 要集, I -64, 1974 年 5 月.

5）山田善一・渡辺英一・中村公信・宮田年耕 ：F.E.M. に よる補剛板の後座屈強度の解析, 日本鋼構造協会 第 9 回 大会研究集会 マトリックス 構造解析法 研究発表 論文集, pp. 233 238, 1975 年 6 月.

6) Yamada, Y. and E. Watanabe : On the behaviour and ultimate strength of Longitudinally stiffened fllanges of steel box girders, Proc. of JSCE, No. 252, pp. 127 $\sim 142$, Aug. 1978.

7）上田幸雄・矢尾哲也・菊本仁司：補剛材の最小剛比につ いて, 日本造船学会論文集，第 140 号， pp. 199 204, 昭和 51 年 11 月, (第 2 報)，第 143 号, pp. 308 315, 昭和 53 年 6 月.

8) Cheung, Y.K. : Finite strip method analysis of slabs, Proc. ASCE, EM 6, pp. 1365 1378, 1968.

9）上田幸雄・松石正克・山内 裕・田中雅子：有限带板法 による平板の弾塑性大たわみ解析, 関西造船協会誌, 第 154 号, pp. 83 92, 昭和 49 年 9 月.

10）上田幸雄・松石正克・森 信義・村川英一：曲げを受け る横桁の最終強度に関する研究, 日本造船学会論文集, 第 139 号, pp. 111 121, 1976 年.

11) Ohtsubo, H. : A method of elastic-plastic analysis of largely deformed plate problems, Proc. Symposium on Application of F.E.M. in Civil Engineering, Vanderbilt Univ., ASCE, pp. 439 456, November 13 14, 
1969.

12）大坪英臣 : 平板の弾塑性大たわみ問題の一解法, 日本造 船学会論文集, 第 130 号, pp. 173 182, 1971 年.

13) Tvergaard, V. and A. Needleman : Buckling of eccentrically stiffened elastic-plastic panels on two simple supports or multiply supported, Int. J. Solids Structures, Vol. 11, pp. 647 663, 1975.

14）小松定夫 ・北田俊行 ・宮崎清司：残留応力および初期た わみを有する圧縮板の弾塑性解析, 土木学会論文報告集, 第 244 号, pp. 1 14, 1975 年 12 月.
15）小松定夫 - 牛尾正之 - 北田俊行：補洞板门溶接残留応力 および初期たわみに関する実験的研究, 土木学会論文報 告集, 第 265 号, pp. 25 35, 1977 年 9 月.

16）小松定夫 - 北田俊行：初期不整を有寸る圧縮板の極限強 度特性に関する研究, 土木学会論文報告集, 第 270 号, pp. $1 \sim 14,1978$ 年 2 月.

17）小松定夫 - 牛尾正之・北田俊行 - 奈良 敬 : 縦横に補剛 された圧縮板の極限強度に関する実験的研究, 土木学会 論文報告集, 第 288 号, pp. 13 28, 1979 年 6 月.

(1978.9.16 - 受付) 